DOI: 10.26693/jmbs03.01.206

UDC 616.39-053.2/.5:616.44

Shushliapina O. V., Budreiko O. A., Shliakhova N. V.

\title{
FEATURES OF C-REACTIVE PROTEIN PRODUCTION DEPENDENCE ON THE PRESENCE OF THYREOPATHY IN CHILDREN WITH OBESITY
}

\author{
State institution «Institute for Children and Adolescents Health Care of the National Academy \\ of Medical Sciences of Ukraine», Kharkiv, Ukraine
}

alenka.shu1980@gmail.com

Determination of the activity of low-intensity inflammation in children with obesity is an urgent task due to its possible pathogenetic role in the formation of thyropathies which may aggravate the course of the disease and cause additional adverse effects of obesity and early formation of metabolic syndrome.

The purpose of the research was to determine the nature of C-reactive protein production in obese children with associated thyropathies.

Materials and methods. Level of C-reactive protein was assessed in 82 children with obesity aged between 6 and 16 years depending on the gender of patients and the presence of concomitant thyropathies (diffuse non-toxic goiter, autoimmune thyroiditis, and minimal changes in the structure of thyroid gland).

Results and Discussion. The mean CRP levels in the group of patients with obesity and thyropathy were significantly higher $(3.9 \pm 1.5 \mathrm{mg} / \mathrm{l}) \mathrm{vs}$. the group of patients without thyropathy $(2.0 \pm 0.7 \mathrm{mg} / \mathrm{I})$ and vs. control $(0.89 \pm 0.25 \mathrm{mg} / \mathrm{I}, \mathrm{p}<0.05)$. Elevated CRP level> $2.0 \mathrm{mg} / \mathrm{I}$ in obese children was more often detected for combination of insulin resistance with thyropathy (53.3\%) compared with a group of patients with thyrotopathy without insulin resistance $(41.4 \%$, $p<0.05)$. In case of diffuse nontoxic goiter in boys with obesity elevated CRP levels were twice as likely to be seen in patients with insulin resistance compared to a group of patients without it.

Conclusions. Low intensity inflammation is closely related to the formation of thyropathies, primarily diffuse nontoxic goiter, in children with obesity, especially in boys. In girls, elevated CRP levels were associated with the development of autoimmune thyroiditis.

Keywords: obesity, thyropathy, C-reactive protein, children.

Problem statement and analysis of recent studies. The particular danger of obesity, prevalence of which in recent decades has become an epidemic, includes progression of metabolic disorders and increased cardiovascular risk in case of long existence of excess body weight. The most expressive are the negative effects of obesity, which began in childhood and adolescence [1]. Among the diseases associated with obesity, in recent years the increasing attention of researchers is attracted by tyreopathies, both among adults and children [3, 13].

Scientific studies have proved that thyroid hormones are important factors involved in the regulation of the basic metabolism and in oxidative metabolism of the human body. In this case, the key connection between the inflammatory and oxidative stress and the development of atherosclerosis is increased level of C-reactive protein (CRP) [8, 11]. It was established that the increased activity of low-intensity inflammation, the most studied marker of which is CRP, is very important for the development of both inflammatory and non-inflammatory thyropathies of different genesis $[4,7,9]$. CRP, like other proinflammatory cytokines, is likely to be responsible for the expansion and increase of permeability of the blood vessels of the thyroid gland, which can lead to pathological changes in the structure and function of the thyroid gland [6].

At the same time, there is no doubt that there is a close link between the increased activity of lowintensity inflammation and insulin resistance (IR), which is confirmed by increased production of proinflammatory cytokines (tumor necrosis factor alphaFNPa, interleukins $1 \beta$ and $6, C R B$ ) in obese patients $[6,12]$. In some works, the nature of CRP production and their association with dysteriosis in obese adults are analyzed [10]. On children, such works are rare and mainly refers to the activity of low-intensity inflammation in obesity, in particular, the increase of CRP production and its gradual decrease against overweight loss in pediatric patients has been proven [5].

Determination of the activity of low-intensity inflammation in obese children is an urgent task due to its possible pathogenetic role in the formation of thyropathies, which may aggravate the course of the disease and cause additional adverse effects of obesity and early formation of metabolic syndrome. 
The purpose of the article was to determine the nature of C-reactive protein production in obese children with associated thyropathies.

Materials and methods. 82 children with obesity aged between 6 and 16 years (39 boys and 43 girls) were examined, with 63 cases of thyroid disease (32 boys and 31 girls), including 44 patients with diffuse nontoxic goiter (DNG), 9 patients with autoimmune thyroiditis (AIT) and 10 patients with obesity with heterogeneity of the thyroid gland structure (HTGS) without autoimmune thyroiditis and without increased volume of the gland itself. Diagnosis of thyroid pathology was carried out by means of palpation and ultrasound examination of thyroid gland, determination of antibodies to thyroglobulin (AbTG) and thyroperoxidase (AbTPO), as well as TTG, free T3 and T4 (fT3, fT4) in blood serum using the immune enzyme method. Determination of high-sensitive CRP was performed by ELISA method on Humareader apparatus. The state of insulin resistance was evaluated according to the HOMA index, which was calculated by the formula: $\mathrm{HOMA}=(\mathrm{G} 0 \times \operatorname{lns} 0) / 22.5$ (where G0 is glucose level in blood plasma on the empty stomach, $\mathrm{mmol} / \mathrm{l}$; Ins0 content of $\mid \mathrm{RI}$ in blood serum on the empty stomach, $\mu \mathrm{U} / \mathrm{ml})$. The presence of $\mathrm{IR}$ in obese patients was diagnosed with a HOMA level higher than $3.5 \mathrm{U}$.

Statistical processing of the results was carried out using Statgraphics centurion XV and the Microsoft Excel 2010 application package. The obtained data are presented in the form of average (M) with standard error of the mean $(\mathrm{m})$, as well as the percentage values for the estimation of the frequencies of elevated values. The probability of difference was measured using parametric (Student $t$-criterion and ANOVA procedure) and non-parametric (Mann-Whitney and Crasack-Wales tests) methods. The critical significance level for statistical hypotheses verification for group comparison was assumed to be 0.05

Results and discussion. The analysis of CRB levels in obese children showed that among patients with thyropathies, elevated CRP levels were slightly higher $(47.6 \%)$ than among obese children without signs of thyroid disease $(36.8 \%)$. At the same time, the prevalence of elevated level of CRP among obese patients in combination with DNG and HTGS (50.0\%) was the highest, slightly lower among patients with AIT (33.3\%). Increased CRP level in the presence of AIT was found only in girls, and in the presence of HTGS - more often in boys $(60.0 \%)$ than in girls $(20.0 \%, p<0.05)$. In case of DNG, the CRB level above $2.0 \mathrm{mg} / \mathrm{L}$ was found to be the same in both boys and girls with obesity ( $52.1 \%$ vs. $47.6 \%)$, which was confirmed by the average CRP, slightly higher among boys with DNG $(5.3 \pm 1.8 \mathrm{mg} / \mathrm{l})$ compared with girls $(3.9 \pm 1.3 \mathrm{mg} / \mathrm{l}, \mathrm{p}<0.1)$ (table).

In general, the average CRP levels in the group of obese patients with thyropathy were significantly higher $(3.9 \pm 1.5 \mathrm{mg} / \mathrm{l})$ as compared to the group of patients without thyropathy $(2.0 \pm 0.7 \mathrm{mg} / \mathrm{l})$ and as compared to the control $(0.89 \pm 0.25 \mathrm{mg} / \mathrm{l}, \mathrm{p}<0.05)$. At the same time among obese patients with AIT elevated CRP level was most noticeable only in girls $3.5 \pm 1.1 \mathrm{mg} / \mathrm{l}$.

Further analysis of obtained data confirmed the existing conception of close connection of low insulin sensitivity to the activity of low-intensity inflammation: pathological changes of CRP (above $2 \mathrm{mg} / \mathrm{I}$ ) occurred in $45.1 \%$ of the subjects, and its average level in patients with signs of IR was higher $(3.8 \pm 1.1 \mathrm{mg} /$ I) than among patients without IR $(2.8 \pm 0.9 \mathrm{mg} / \mathrm{I}$, and compared with the control group - $0.89 \pm 0.25 \mathrm{mg} / \mathrm{I}, \mathrm{p}$ $<0.05)$. At the same time in case of IR the incidence of CRP elevation in girls was higher than that of boys ( $57.1 \%$ vs. $41.2 \%$, respectively, $p<0.05)$, and in the case of normal insulin sensitivity, the incidence of elevated CRP, depending on sex, was not significantly different $(42.0 \%$ in boys versus $38.1 \%$ in girls).

It should be noted that elevation of CRP> $2.0 \mathrm{mg} / \mathrm{I}$ among obese children was more often detected for IR combination with thyropathy $(53.3 \%)$ compared to a

Table 1 - The level of CRB depending on the presence of thyropathy in children with obesity $(\mathrm{mg} / \mathrm{l})$

\begin{tabular}{l|c|c|c|c|c|c}
\multicolumn{1}{c|}{$\begin{array}{c}\text { Group of patients } \\
\text { with obesity }\end{array}$} & $\mathrm{n}$ & Total & $\mathrm{n}$ & Boys & $\mathrm{n}$ & Girls \\
\hline All children & 82 & $3.5 \pm 1.5$ & 39 & $3.9 \pm 1.3$ & 43 & $3.1 \pm 1.2$ \\
\hline Children with thyropathy & 63 & $3.9 \pm 1.5^{*}$ & 32 & $4.4 \pm 1.6^{*}$ & 31 & $3.6 \pm 1.1^{*}$ \\
\hline Children without thyropathy & 19 & $2.0 \pm 0.7$ & 7 & $1.9 \pm 0.7$ & 12 & $2.0 \pm 0.6$ \\
\hline Children with DNG & 44 & $4.6 \pm 1.8^{*}$ & 23 & $5.3 \pm 1.8^{*}$ & 21 & $3.9 \pm 1.3^{*}$ \\
\hline Children with AIT & 9 & $2.5 \pm 0.9$ & 4 & $1.2 \pm 0.5$ & 5 & $3.5 \pm 1.1^{*}$ \\
\hline Children with HTGS & 10 & $2.6 \pm 1.0$ & 5 & $2.7 \pm 1.0$ & 5 & $2.4 \pm 0.9$ \\
\hline Control group & 25 & $0.9 \pm 0.2$ & 12 & $0.8 \pm 0.1$ & 13 & $1.0 \pm 0.2$ \\
\hline
\end{tabular}

Note: ${ }^{*} p<0.05$ the probability of differences in the group of patients without thyropathy. 


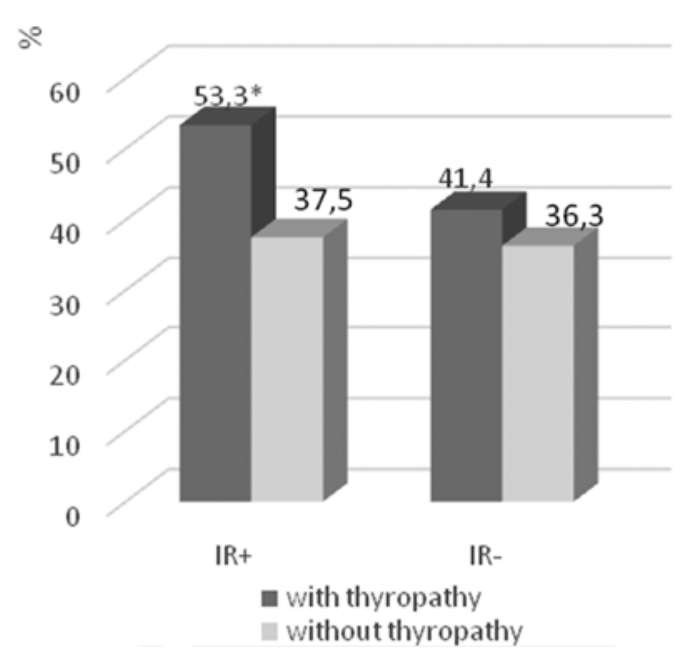

a)

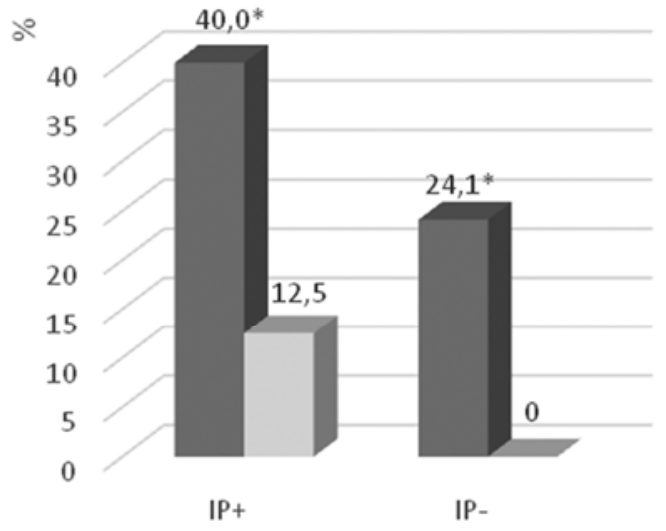

Insulin resistance

with thyropathy $\quad$ without thyropathy

b)

Fig. 1 Frequency of elevated CRP in obese children depending on the presence of thyropathy and insulin resistance a) level of CRP $>2.0 \mathrm{mg} / \mathrm{l} ; b$ ) level of CRP $>4.0 \mathrm{mg} / \mathrm{l}$

Notes: ${ }^{*} p<0.05$ Probability of differences in the parameters of the group of patients without thyropathy with the same state of insulin resistance; IR+ - presence of insulin resistance; IR- - no insulin resistance

group of patients with thyropathy but without IR $(41.4 \%, p<0.05)$ In patients with obesity but without thyropathy, the incidence of CRP elevation above $2.0 \mathrm{mg} / \mathrm{L}$ did not significantly depend on the state of insulin sensitivity $(37.5 \%$ in the presence of IR and $36.3 \%$ in the absence of IR) (Fig. 1a).

Analysis of manifestations of more distinct lowintensity inflammation with greater probability confirmed its close association with thyropathies in obese children, which was manifested by elevated frequency of $\mathrm{CRP}>4.0 \mathrm{mg} / \mathrm{I}$ in patients with thyroid disease in the presence of IR $(40.0 \%$ vs $12.5 \%$ in the group of patients without thyropathy, $\mathrm{p}<0.05$ ) and without IR (24.1\% along with no increase of CRP $>4.0 \mathrm{mg} / \mathrm{I}$ in the group of patients without thyropathy) (Fig. 1b).

In case of DNG, as the most frequent type of thyroiditis that is combined with obesity, the severity of low intensity inflammation was most closely related to the IR in boys with a 2.5 -fold increase of $C R P>2.0 \mathrm{mg} / \mathrm{L}$, and CRP> $4.0 \mathrm{mg} / \mathrm{I}-$ twice as often among patients with an IR compared to a group of patients without IR (Fig. 2a, b). In girls, the incidence of elevated CRP

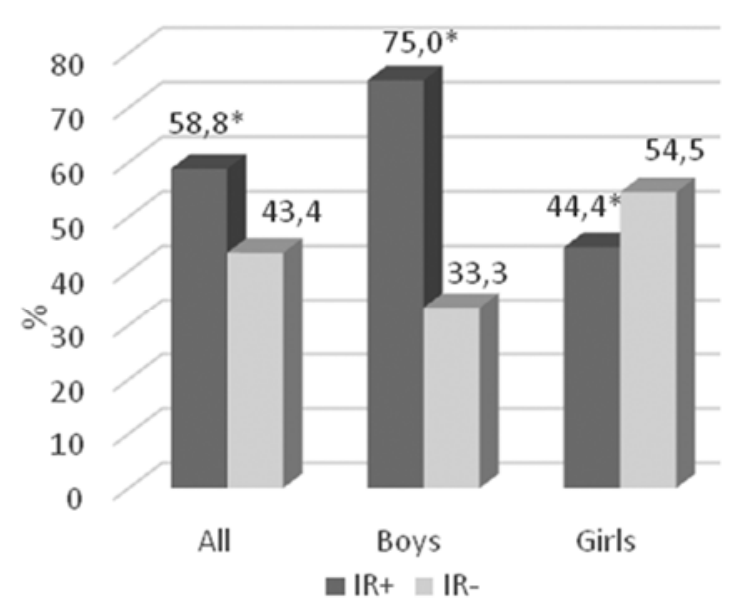

a)

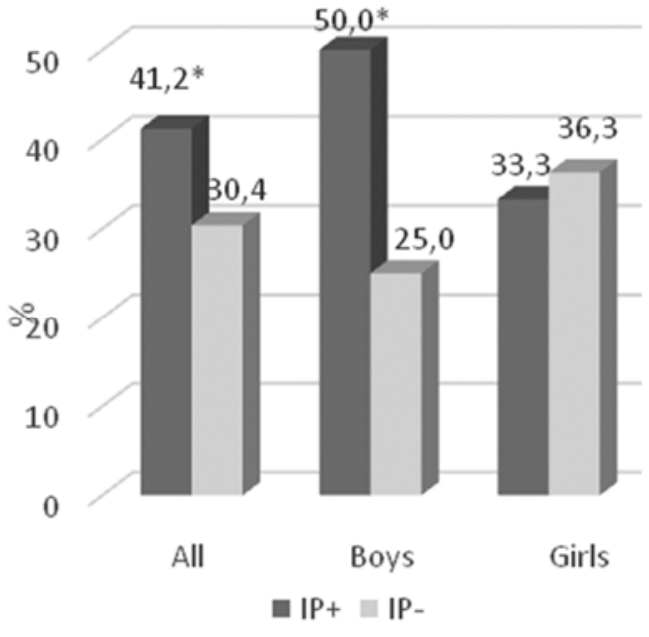

b)

Fig. 2. Frequency of elevated CRP in children with obesity with diffuse nontoxic goiter depending on gender and presence of insulin resistance, a) - level of CRP> $2.0 \mathrm{mg} / \mathrm{l} ; b)-\mathrm{CRP}>4.0 \mathrm{mg} / \mathrm{l}$

Notes: * $p<0.05$ Probability of differences in the parameters of the group of patients without insulin resistance; IR+ - presence of insulin resistance; IR- - no insulin resistance. 
levels was significantly lower than that of boys and did not significantly depend on the presence of IR.

Thus, in obese children, as in adults, increased production of high-sensitivity CRP, which is a likely marker of low-intensity inflammation activity, was found. The influence of this pathogenic factor on the formation of thyropathies is to some extent related to the gender and may be due to immunomodulatory effects of sex steroids, which is consistent with the results of other scientific studies [2]. Obtained results indicate the importance of the connection of reduced insulin sensitivity and severity of low-intensity inflammation in the formation of thyropathies in obese children.

\section{Conclusions}

1. The presence of low intensity inflammation is confirmed in children with obesity, which is closely related to the formation of thyropathies, primarily diffuse nontoxic goiter.

2. The effect of low-intensity inflammation on the formation of thyropathies in obese children has gender differences: in boys, elevated CRP levels are associated with the development of diffuse non-toxic goiter, and in girls - with the development of autoimmune thyroiditis.

Prospects for further research. Important areas of scientific research on the formation of thyropathies in obese children are the study of the possible joint effect of IR and low intensity inflammation on the development of elevated TSH in blood as well as the mechanisms of the influence of sex steroids and other hormones on the development of thyroid gland damage in patients of different genders.

\section{References}

1. Panova El, Martyshina OV, Danilov VA. Associirovannaja s ozhireniem patologija: chastota, harakter i nekotorye mehanizmy formirovanija [Obesity associated pathology: frequency, character and some mechanisms of formation]. Sovremennye tehnologii $v$ medicine. 2013; 5 (2): 108-15. [Russian].

2. Shuplecova VV, Gucol AA, Haziahmatova OG, Sohonevich NA, Jurova KA, Litvinova LS. Vlijanie polovyh steroidnyh gormonov (testosterona i $\beta$-jestradiola) na produkciju pro- i antivospalitel'nyh citokinov aktiviro-vannymi T-limfocitami raznoj stepeni [digital resourse]. Citokiny i vospalenie. 2015; 1. Available from: http://www.cytokines.ru/russian/2015/1/ Art10.php. [Russian].

3. Chen H, Zhang H, Tang W, Xi Q, Liu X, Duan Y, Liu C. Thyroid function and morphology in overweight and obese children and adolescents in a Chinese population. J Pediatr Endocrinol Metab. 2013; 26 (5-6): 489-96. PMID: 23509206. doi: 10.1515/jpem-2012-0299.

4. Czarnywojtek A, Owecki M, Zgorzalewicz-Stachowiak M, Woliński K, Szczepanek-Parulska E, Budny B, et al. The Role of Serum C-Reactive Protein Measured by High-Sensitive Method in Thyroid Disease. Archivum Immunologiae et Therapiae Experimentalis. 2014 May; 62 (6): 501-9. PMCID: PMC4244578. doi: 10.1007/s00005-014-0282-1.

5. Garanty-Bogacka B, Syrenicz M, Goral J, Krupa B, Syrenicz J, Walczak M, Syrenicz A. Changes in inflammatory biomarkers after successful lifestyle intervention in obese children. Endokrynol Pol. 2011; 62 (6): 499-505. PMID: 22144215.

6. Huh JY, Park YJ, Ham M, Kim JB. Crosstalk between adipocytes and immune cells in adipose tissue inflammation and metabolic dysregulation in obesity. Mol Cells. 2014; 37: 365-71. PMID: 24781408. PMCID: PMC4044307. doi: 10.14348/molcells.2014.0074.

7. Jublanc C, Bruckert E, Giral P, Chapman MJ, Leenhardt L, Carreau V, Turpin G. Relationship of circulating C-reactive protein levels to thyroid status and cardiovascular risk in hyperlipidemic euthyroid subjects: low free thyroxine is associated with elevated hsCRP. Atherosclerosis. 2004; 172 (1): 7-11. PMID: 14709351. https://doi.org/10.1016/ j.atherosclerosis.2003.09.009.

8. Mancini A, Di Segni C, Raimond S, Olivieri G, Silvestrini A, Meucci E, Currò D. Thyroid Hormones, Oxidative Stress, and Inflammation. Mediators of Inflammation. 2016; 2016, Article ID 6757154, 12 pages. Available from: from https:/l www.hindawi.com/journals/mi/2016/6757154/. PMID: 27051079. PMCID: PMC4802023. DOI: 10.1155/2016/6757154.

9. Pearce EN, Fausto B, Martino E, Brogioni S, Pardini E, Pellegrini G, et al. The Prevalence of Elevated Serum CReactive Protein Levels in Inflammatory and Noninflammatory Thyroid Disease. Thyroid. 2004; 13 (7): 643-8. https:// doi.org/10.1089/105072503322239989.

10. Shantha GP, Kumar AA, Jeyachandran V, Rajamanickam D, Rajkumar K, Salim S, Subramanian KK, Natesan S. Association between primary hypothyroidism and metabolic syndrome and the role of $C$ reactive protein: a crosssectional study from South India. Thyroid Res. 2009 Mar; 2 (1): 2. PMID: 19272156. PMCID: PMC2655275. doi: 10.1186/1756-6614-2-2.

11. Singh S, Dey Sarkar P. Serum lipids, tHcy, hs-CRP, MDA and PON-1 levels in SCH and overt hypothyroidism: effect of treatment. Acta Biomed. 2014 Aug 20; 85 (2): 127-34. PMID: 25245648.

12. Wieser $\mathrm{V}$, Moschen AR, Tilg $\mathrm{H}$. Inflammation, cytokines and insulin resistance: a clinical perspective. Arch Immunol Ther Exp (Warsz). 2013 Apr; 61 (2): 119-25. PMID: 23307037. doi: 10.1007/s00005-012-0210-1.

13. Witkowska-Sędek E, Kucharska A, Rumińska M, Pyrżak B. Thyroid dysfunction in obese and overweight children. Endokrynol Pol. 2017; 68 (1): 54-60. doi: 10.5603/EP.2017.0007.

14. Zhao Y, Lv G. Correlation of C-reactive protein level and obesity in Chinese adults and children: a meta-analysis. $J$ Endocrinol Invest. 2013 Sep; 36 (8): 642-7. PMID: 23765545. doi: 10.3275/9004. 
Удк 616.39-053.2/.5:616.44

ОСОБЛИВОСТІ ПРОДУКЦІЇ С-РЕАКТИВНОГО ПРОТЕЇНУ В ЗАЛЕЖНОСТІ

ВІД НАЯВНОСТІ ТИРЕОПАТІЙ У ДІТЕЙ, ХВОРИХ НА ОЖИРІННЯ

Шушляпіна О. В., Будрейко О. А., Шляхова Н. В.

Резюме. Визначення активності низькоінтенсивного запалення при ожирінні у дітей є актуальним завданням через його можливу патогенетичну роль у формуванні тиреопатій, які можуть обтяжувати перебіг захворювання та обумовлювати додаткові негативні наслідки ожиріння і раннє формування метаболічного синдрому.

Мета - визначити характер продукції С-реактивного протеїну у дітей, хворих на ожиріння, із супутніми тиреопатіями.

Матеріали і методи. У 82 дітей 6-16 років, хворих на ожиріння досліджено рівень С-реактивного протеїну, який оцінювався в залежності від статі хворих та наявності супутніх тиреопатій (дифузний нетоксичний зоб, автоімунний тиреоїдит, мінімальні зміни структури щитоподібної залози).

Результати. Середні рівні СРП в групі хворих на ожиріння з тиреопатіями виявились вірогідно вищи-

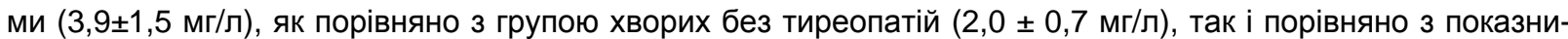
ком контролю $(0,89 \pm 0,25$ мг/л, p < 0,05). Підвищення рівня СРП>2,0 мг/л серед дітей з ожирінням частіше виявлялось за умови поєднання інсулінорезистенності з тиреопатією (53,3\%), порівняно з групою хворих з тиреопатіями без інсулінорезистенності $(41,4 \%, p<0,05)$. При дифузному нетоксичному зобі у хлопців з ожирінням підвищений рівень СРП виявлявся вдвічі частіше серед хворих з інсулінорезистентністю, порівняно з групою хворих без неї.

Висновки. У дітей з ожирінням низькоінтенсивне запалення тісно пов'язане з формуванням тиреопатій, передусім дифузного нетоксичного зоба, особливо у хлопців. У дівчат підвищення рівня СРП більшою мірю пов'язане з розвитком автоімунного тиреоїдиту.

Ключові слова: ожиріння, тиреопатії, С-реактивний протеїн, діти.

\section{Удк 616.39-053.2 / .5: 616.44}

\section{ОСОБЕННОСТИ ПРОДУКЦИИ С-РЕАКТИВНОГО ПРОТЕИНА В ЗАВИСИМОСТИ ОТ НАЛИЧИЯ ТИРЕОПАТИЙ У ДЕТЕЙ, БОЛЬНЫХ ОЖИРЕНИЕМ \\ Шушляпина Е. В., Будрейко Е. А., Шляхова Н. В.}

Резюме. Определение активности низкоинтенсивного воспаления при ожирении у детей является актуальной задачей из-за его возможной патогенетической роли в формировании тиреопатий, которые могут отягощать течение заболевания и обусловливать дополнительные негативные последствия ожирения и раннее формирование метаболического синдрома.

Цель - определить характер продукции С-реактивного протеина у детей, больных ожирением, с сопутствующими тиреопатиями.

Материалы и методы. У 82 детей 6-16 лет, больных ожирением исследован уровень С-реактивного протеина, который оценивался в зависимости от пола больных и наличия сопутствующих тиреопатий (диффузный нетоксичный зоб, аутоиммунный тиреоидит, минимальные изменения структуры щитовидной железы).

Результаты. Средние уровни СРП в группе больных ожирением с тиреопатией оказались достоверно выше (3,9 $\pm 1,5$ мг / л) как по сравнению с группой больных без тиреопатий $(2,0 \pm 0,7$ мг / л), так и по сравнению с показателем контроля $(0,89 \pm 0,25$ мг / л, p <0,05). Повышение уровня СРП> 2,0 мг / л среди детей с ожирением чаще оказывалось при условии сочетания инсулинорезистенности с тиреопатией (53,3\%), по сравнению с группой больных с тиреопатиями без инсулинорезистенности $(41,4 \%, p<0,05)$. При диффузном нетоксичном зобе у детей с ожирением повышенный уровень СРП определялся вдвое чаще среди больных с инсулинорезистентностью, по сравнению с группой больных без нее.

Выводы. У детей с ожирением низкоинтенсивное воспаление тесно связано с формированием тиреопатий, прежде всего диффузного нетоксического зоба, особенно у мальчиков. У девочек повышение уровня СРП большей мерой связано с развитием аутоиммунного тиреоидита.

Ключевые слова: ожирение, тиреопатии, С-реактивный протеин, дети.

Стаття надійшла 17.11.2017 p. Рекомендована до друку на засіданні редакційної колегії після рецензування 